\title{
Geochemistry and Organic Petrography of Jordanian Sultani Oil Shale
}

\author{
Hani Alnawafleh ${ }^{*}$, Khalid Tarawneh ${ }^{2}$, George Siavalas ${ }^{3,4}$, Kimon Christanis ${ }^{3}$, Andreas Iordanidis ${ }^{5}$ \\ ${ }^{1}$ Department of Mining and Mineral Engineering, Al-Hussein Bin Talal University, Ma'an, Jordan \\ ${ }^{2}$ Department of Civil Engineering, Isra University, Amman, Jordan \\ ${ }^{3}$ Department of Geology, University of Patras, Patras, Greece \\ ${ }^{4}$ Shell Global Solutions International B.V, Hague, The Netherlands \\ ${ }^{5}$ Department of Geotechnology and Environmental Engineering, Technological Educational Institute (TEI) of Western Macedonia, Kila, \\ Kozani, Greece \\ Email: ${ }^{*}$ Hanialnawafleh@ahu.edu.jo
}

How to cite this paper: Alnawafleh, H., Tarawneh, K., Siavalas, G., Christanis, K. and Iordanidis, A. (2016) Geochemistry and Organic Petrography of Jordanian Sultani Oil Shale. Open Journal of Geology, 6, 12091220.

http://dx.doi.org/10.4236/ojg.2016.610089

Received: September 7, 2016

Accepted: September 27, 2016

Published: September 30, 2016

Copyright (c) 2016 by authors and Scientific Research Publishing Inc. This work is licensed under the Creative Commons Attribution International License (CC BY 4.0).

http://creativecommons.org/licenses/by/4.0/ (c) (†) Open Access

\begin{abstract}
The Sultani oil shale (OS) deposit is considered as a major fossil fuel source in Jordan. Applying various petrographic and geochemical techniques, this paper aims to study the Sultani OS geochemical and organic petrographic features. Results show that Sultani OS is a bituminous limestone consisting of very fine-grained matrix with rippled micro-laminated texture and muddy material of cryptocrystalline micrite. The rock is rich in Cretaceous microfossil shells filled in organic matter (OM). The filling $\mathrm{OM}$ is bitumen of the migrabitumen type. The OM content reaches up to 17 wt.\% with high oil-yielding capacity (up to $12 \mathrm{wt} . \%$ ). High TOC values suggest that the Sultani OS has a very good source rock potential. Organic petrography shows low OM maturity level and reveals two varieties of vitrinite, namely primary and oxidized vitrinite. The latter is derived from terrestrial plant tissues. Additionally, liptinite macerals including alginite and to a lesser extent cutinite, also participate. Various diagenetic features such as pyrite replacement and bitumen thermal alteration have been recorded. Results suggest that Sultani OS is a marinite formed under marine conditions with limited contribution of terrestrial OM input.
\end{abstract}

\section{Keywords}

Oil Shale, Jordan, Bitumen, Organic Matter, Vitrinite Reflectance, Macerals

\section{Introduction}

Oil shale (OS) is an organic-rich, fine-clastic sedimentary rock containing significant amounts of kerogen, which expels oil upon heating [1]. Oil shale contains more than 
$5 \%$ of organic matter $(\mathrm{OM})$. The diverse composition of $\mathrm{OM}$ in oil shales indicates a wide range of sedimentary depositional environments [2]. The OM in OS is composed of bitumen and kerogen [3]. Bitumen fraction is soluble in most organic solvents and depends on the thermal maturity and the kerogen to bitumen transformation ratio. However, kerogen composes the bulk of the OM in OS [1]. Economic OS must have a significant proportion of organic matter [4]. Analysis of OM in organic-rich sedimentary rocks provides significant information for the reconstruction of depositional paleoenvironments [5].

The microscopically recognizable individual OM constituents of OS and other sedimentary rocks are called macerals. The macerals are classified into three major groups: vitrinite, inertinite, and liptinite [6]. Macerals in OS are distinguished by their optical characteristics, namely their reflectance and fluorescence [4]. The thermal maturity of $\mathrm{OM}$ is commonly expressed in terms of vitrinite reflectance. Reflectance is a property related to the aromaticity of the organic components [5]; as thermal evolution causes changes in the chemical composition of vitrinite and solid bitumen results in the increase of their reflectance values [7], [8]. Vitrinite reflectance has been widely used to assess the thermal maturity in organic-rich rocks.

Jordan has limited resources of oil and natural gas. However, there are nearly 26 commercial oil shale (OS) deposits found in Jordan [9]. More than $50 \mathrm{Gt}$ of OS are reported in the middle and southern parts of the country with unknown reserves in the north [10]. The Sultani OS deposit is one of the most important central Jordan OS deposits (Figure 1) covering an area of $24 \mathrm{~km}^{2}$ with geological reserves exceeding $1130 \mathrm{Mt}$

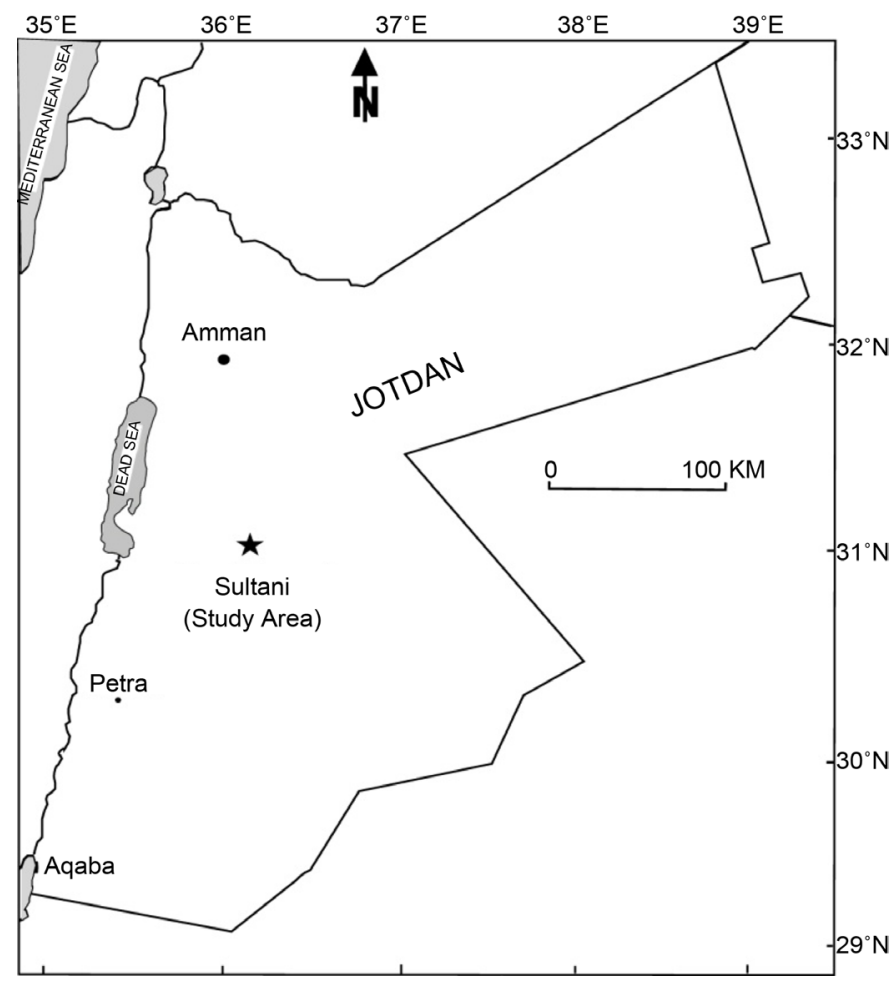

Figure 1. Location of Sultani oil shale deposit. 
[11]. The OS in Sultani area is found at shallow depths and in the form of horizontal beds, where $90 \%$ or more is favorable for opencast mining techniques [12], [13]. Oil shale thickness is about $32 \mathrm{~m}$ while the overburden reaches up to $70 \mathrm{~m}$. Based on analyses from 60 boreholes, the average oil yield reported by the Natural Resources Authority (NRA) is $7.5 \mathrm{wt} . \%$ [11].

Previous work on Sultani OS gave more attention to the deposit evaluation and mining related issues. An important evaluation of Sultani OS is the study carried out by Hufnagel [14]. Still many aspects of Sultani OS characterization require more detailed investigation. This paper presents a geochemical and petrographic study of the Sultani OS. The micro-textures, composition, and organic matter (OM) sources are studied aiming to shed light on the genesis of OS at this location. The findings of this study will be of valuable importance in any future OS evaluation studies on both local and regional scales, and for research on similar material in the region.

\section{Geologic Setting}

The Jordanian OS is a kerogen-rich, bituminous calcareous rock of the Muwaqqar Chalk Marl Formation (MCM), formed within marine environment of Late Cretaceous (Maastrichtian) to early Tertiary age [15]-[17]. Based on report by Andrews [18], the MCM shows some important differences in lithology from one location to another. The Jordanian OS forming part of the South Tethyan oil shale-phosphorite giant belt, extends from Morocco to Syria [19]. A thick sequence of calcareous rocks was deposited over the northern and central parts of Jordan. The sedimentation of this sequence was controlled by the configuration of the Neo-Tethys Ocean and its subsequent closure, sea level fluctuation, and tectonic activities prevailed at that time interval [20]-[24].

At shallow depths the OS deposits in central Jordan are underlain by phosphatic limestone and chert of the phosphorite unit [11], [23]. The overburden is composed of chalk and marl beds covered by unconsolidated gravel and silt (Figure 2). The Sultani OS was deposited in synclinal basins [25] bounded by faults [14]. Overall, the OS thickness increases northwards toward the Yarmouk deposit in the north of Jordan where it reaches more than $280 \mathrm{~m}$ in thickness [16], [23].

Abed et al. [25] and Dill et al. [17] reported that central Jordan OS was formed on the southern epicontinental shelf of the Tethys Ocean where upwelling currents enhanced bioproductivity and increased sedimentation rates. Bottom water conditions prevailed during the OS formation is the major factor that controlled OM preservation. Conditions were changed from oxic during phosphate formation to sub-oxic to anoxic during OS formation [16], [23].

\section{Material and Methods}

One oil shale sample was collected from OS exposure at the Sultani open pit excavated by the Natural Resources Authority (NRA) of Jordan (Figure 3). The exposed OS surface is buff-creamy and whitish in colour due to weathering processes. The weathered surface of OS was firstly cleaned using hammer and chisel, and then one fresh OS sample 


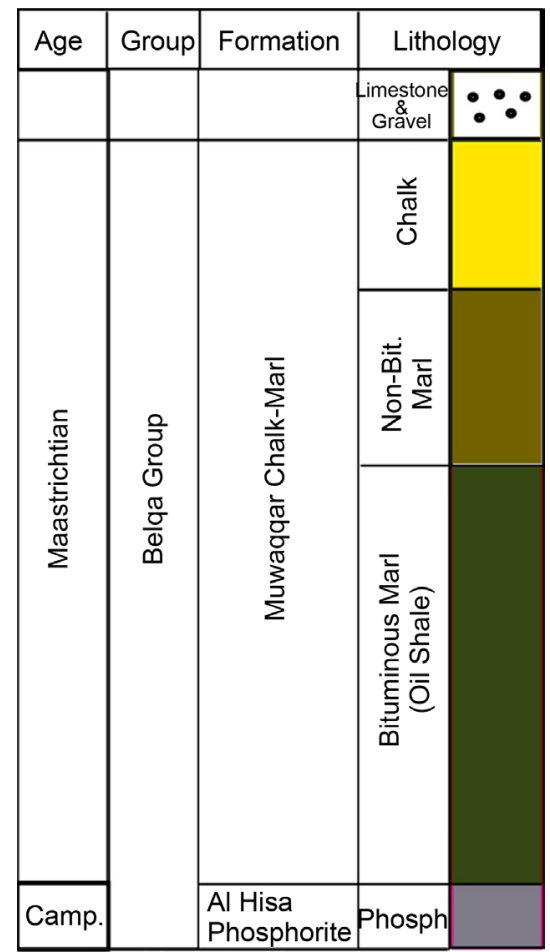

Figure 2. Simplified litho-stratigraphic column (not to scale) of upper cretaceous rock formations in Sultani.

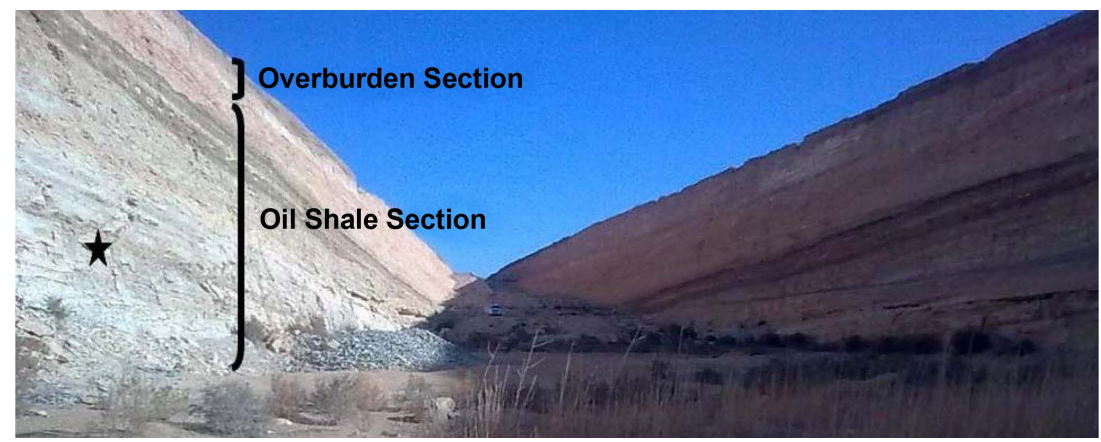

Figure 3. Oil shale exposure at Sultani open pit. Star refers to sample location.

was obtained. Thin chips of OS sample were cut for the purpose of thin section and polished blocks preparation. The rest of the sample was crushed using jaw crusher. The crushed part then was finely ground using a ball mill to less than 75 microns.

One polished OS thin section was prepared to study the internal texture and features via the polarizing microscope. Photomicrographs of OS in the polished thin section were taken using a Canon Power Shot S70 digital camera. Sultani OS mineralogical composition was examined using the XRD PHILIPS (XPERT MPD) X-ray power diffraction set. The total organic carbon (TOC) content was indirectly determined using carbon determinator (thermal conductivity detector). The OS sample was analysed for its chemical content by ICP-MS. The quality of Sultani OS was obtained from the Fisher assay analysis that was performed using the Fisher assay equipment at the NRA. 
Organic-petrology analysis focused on maceral determination and vitrinite reflectance measurement. Macerals were defined based on the nomenclature applied by the International Committee for Coal Geology (ICCP, 6), Hutton [26], and Taylor et al. [4]. Two polished blocks, one from the whole rock and one from the light fraction ( $\mathrm{sg}<1.6$ $\mathrm{g} / \mathrm{cm}^{3}$ ) of Sultani OS were prepared in order to study its organic petrography features. Both blocks were examined under a Leica DMRX coal petrography microscope. The whole-rock polished block was chosen for reflectance measurements. Photomicrographs were taken under white incident light and blue light excitation in oil immersion on a perpendicular to bedding polished block of the whole rock and the light fraction as well.

\section{Results and Discussion}

\subsection{Major Components and Mineralogy}

The XRD results are shown in Figure 4. The major mineral fraction in Sultani OS is carbonate, mainly calcite. Calcite is the major mineral in all Jordanian OS deposits [27]. This domination of calcite indicates that Sultani OS is a calcareous organic-rich sedimentary rock and not true shale. Minor content of quartz and traces of phosphate and clay are also present in the Sultani OS.

The chemical composition of Sultani OS sample is given in Table 1. The major oxide component is $\mathrm{CaO}$ which is mainly attributed to calcite and minor amounts presumably associated with apatite and gypsum. Other major oxides show different values.

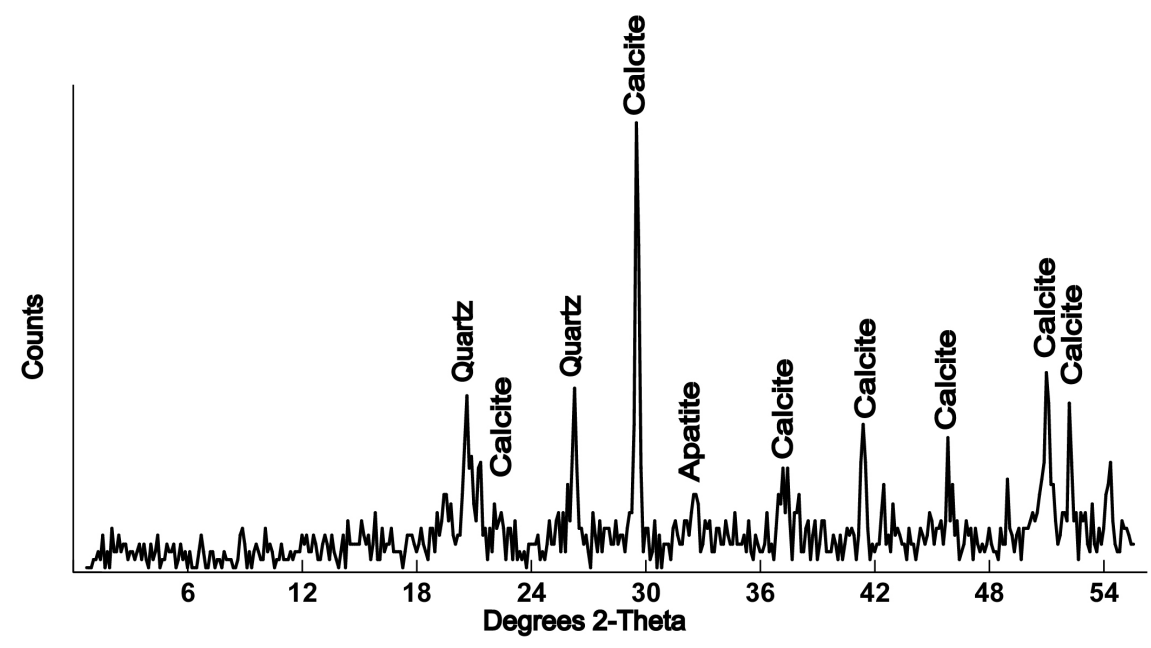

Figure 4. X-ray diffractogram from Sultani OS.

Table 1. Whole-rock analysis of major and selected trace elements of the Sultani OS sample.

\begin{tabular}{cccccccc}
\hline & $\mathrm{CaO}$ & $\mathrm{Al}_{2} \mathrm{O}_{3}$ & $\mathrm{Fe}_{2} \mathrm{O}_{3}$ & $\mathrm{MgO}$ & $\mathrm{P}_{2} \mathrm{O}_{5}$ & $\mathrm{SO}_{3}$ & $\mathrm{TiO}_{2}$ \\
Major Oxide (wt.\%) & 22.2 & 2.8 & 1.3 & 2.0 & 4.1 & 5.9 & 0.1 \\
\hline \multirow{2}{*}{ Trace Element (ppm) } & $\mathrm{Cr}$ & $\mathrm{Cu}$ & $\mathrm{Mn}$ & $\mathrm{Ni}$ & $\mathrm{Sr}$ & $\mathrm{V}$ & $\mathrm{Zn}$ \\
& 289 & 60 & 45 & 111 & 641 & 248 & 519 \\
\hline
\end{tabular}


$\mathrm{Al}_{2} \mathrm{O}_{3}$ is a main component in clay minerals. High $\mathrm{P}_{2} \mathrm{O}_{5}$ is evident of the presence of phosphate minerals in Sultani OS and indicates high levels of OM production. $\mathrm{SO}_{3}$ is associated with OM, sulfides, and gypsum. High sulfur content is indicative of high primary productivity. High OM productivity is also suggested based on the enrichment in most trace elements.

\subsection{Detail of Internal Texture}

Sultani OS is bituminous calcareous marl and consists of organic matter (OM) and very fine-grained matrix (Figure 5). The matrix strongly shows rippled micro-laminated texture and consists mainly of muddy material of cryptocrystalline micrite. Cretaceous microfossils (mostly forams) are abundant, and brown organic matter fills pore spaces. Quartz crystals are distributed in the groundmass. They may be syn- or post-depositional [25]. Iron oxides found as anhedral crystals of black spots. Micro-fissures are sparse, empty and show druzy texture as white calcite grew around the cavities.

\subsection{Organic Matter Content and Oil Shale Quality}

The OM content is inferred from the results of total organic carbon (TOC) content. TOC in Sultani OS is about $13.5 \mathrm{wt}$ \%, which is equivalent to $17 \%$ OM [28]. Quite high TOC indicates that Sultani OS has very good source rock generative potential [29]. TOC-rich sedimentary rocks are commonly related to: anoxia [30], enhanced OM preservation [31], and high surface water productivity [32]. The TOC value can be reduced by oxidation of OM during outcrop weathering [29].

The Fisher assay analysis (Figure 6) confirms that Sultani OS is of good quality as the

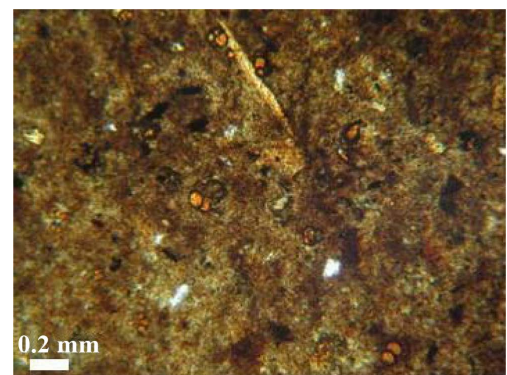

Figure 5. Transmitted white light photomicrograph of Sultani OS taken under plane polarized light (PPL) and $4 \times$ magnification.

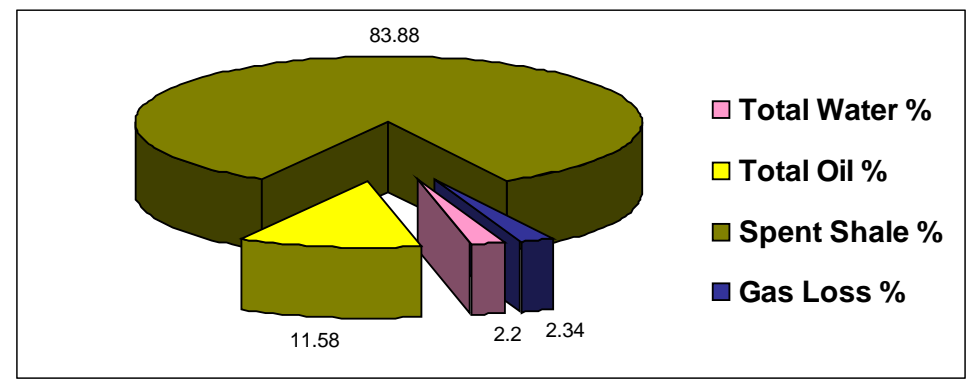

Figure 6. The results of fisher assay analysis. 
oil content is about 12 wt.\%. The shale oil yield depends on the nature and abundance of kerogen in OS, as well as on OS thermal maturity [2].

\subsection{Organic Petrography}

Organic petrography analysis of the Sultani OS revealed that bituminite is the main kerogen maceral with alginite, primarily composed of dinoflagellate cysts and acritarchs, being second. Prasinophytae alginite (tasmanites and leiosphaeridia) is very rare in this sample. There is also limited contribution from terrestrial organic matter found in the form of vitrodetrinite (vitrinite fragments-Figure 7) and fusinite (burned/oxidised plant remains-Figure 8). Mean random vitrinite reflectance $\left(\mathrm{Rr}_{\mathrm{oil}}\right)$ is $0.85 \%$; however, all of the measured vitrinite grains bear evidence of oxidation suggesting that they have been subjected to more than one sedimentation cycles. Therefore, vitrinite reflectance is not a very reliable parameter to assess the thermal maturity of this OS. Various zooclasts, calcareous at the most part, are also present (Figure 9). Multi-chambered foraminifera test linings are the main type with large-sized elongated zooclasts, presumably derived from fish remains being also common.

Two types of solid bitumens (migrabitumens) were also observed (Figure 10). The first type is low reflecting $\left(\mathrm{Rr}_{\mathrm{oil}}<0.10 \%\right)$ and in most of the cases, appears to fill the cavities of foraminifera shells (Figure 9 and Figure 11). This bitumen type also displays yellow fluorescence, similar to this of alginite; according to bitumen classification [33] it is called wurtzilite (Figure 11). This bitumen was probably expelled from the kerogen (both bituminite and alginite) and consequently, filled the foraminifera chambers. The
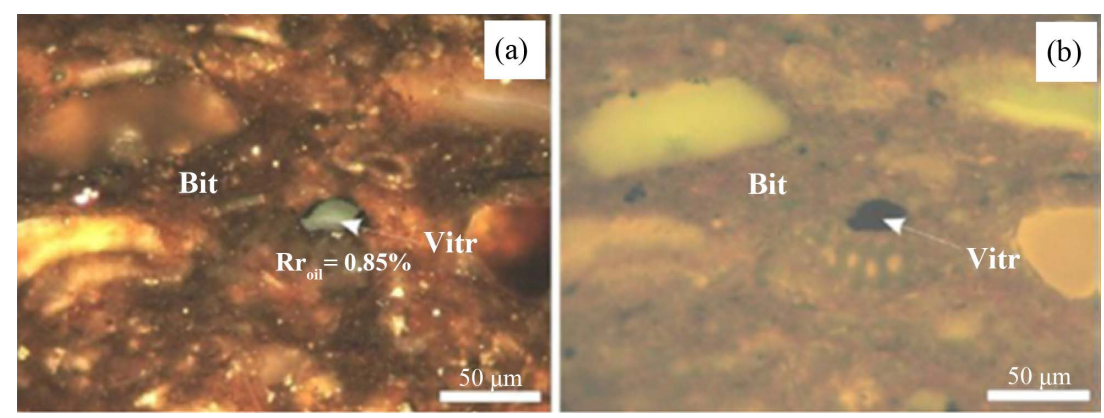

Figure 7. Vitrinite particle (vitr) in bituminite (bit) and mineral matter matrix under (a) white reflected light, (b) fluorescence mode.
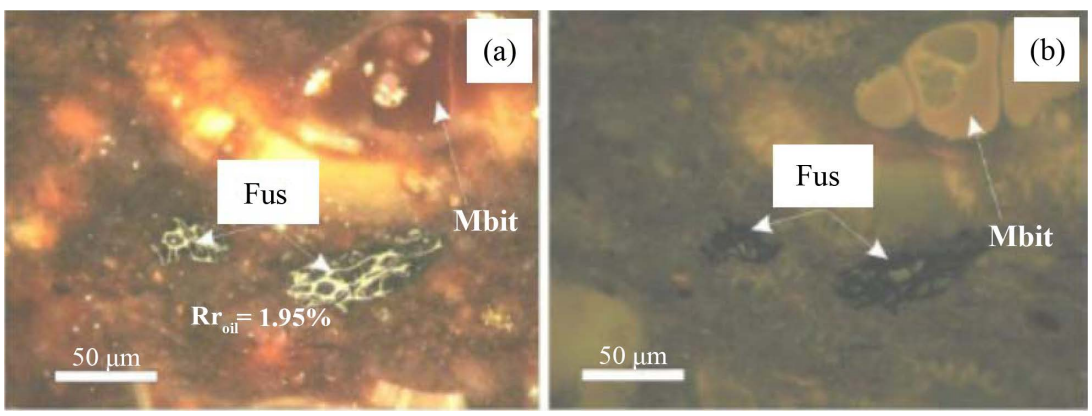

Figure 8. Fusinite (Fus) under (a) white reflecting light, (b) fluorescence mode. 

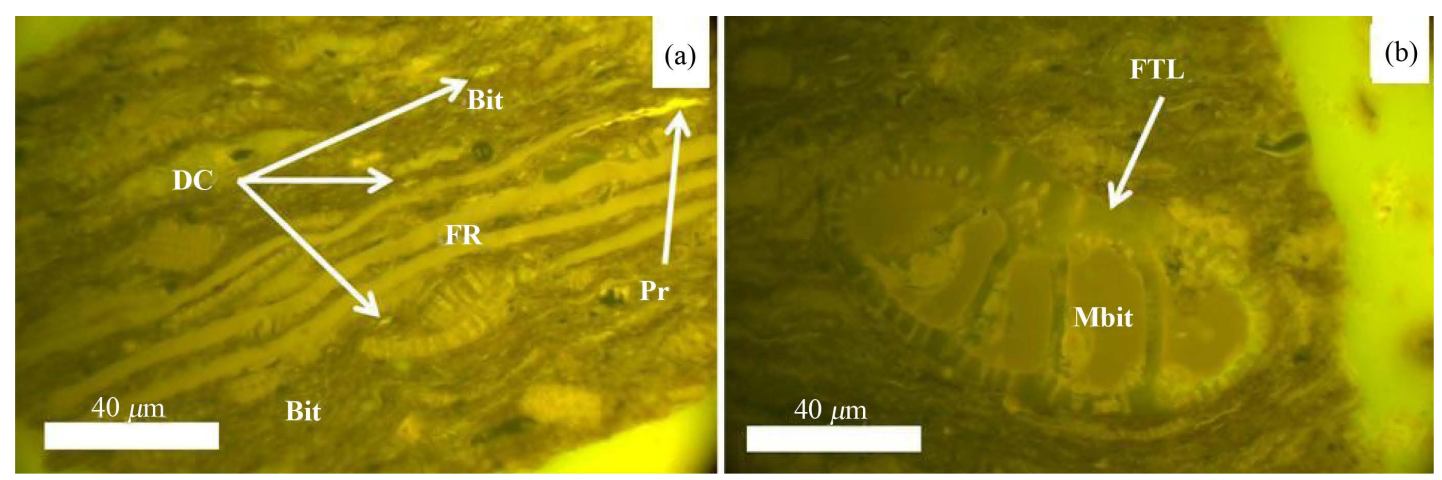

Figure 9. (a) Bituminite (Bit) is the major maceral in the Sultani OS followed by alginite (primarily dinoflagellate cysts (DC) and rarely leiosphaeridia (Pr)). Fish remains (FR) are also common; (b) Foraminifera test linings (FTL) are the most common form of calcareous zooclasts in this OS. They are often filled with wurtzilite (Mbit-low-reflecting, fluorescing solid bitumen). Both photomicrographs taken in fluorescence mode.
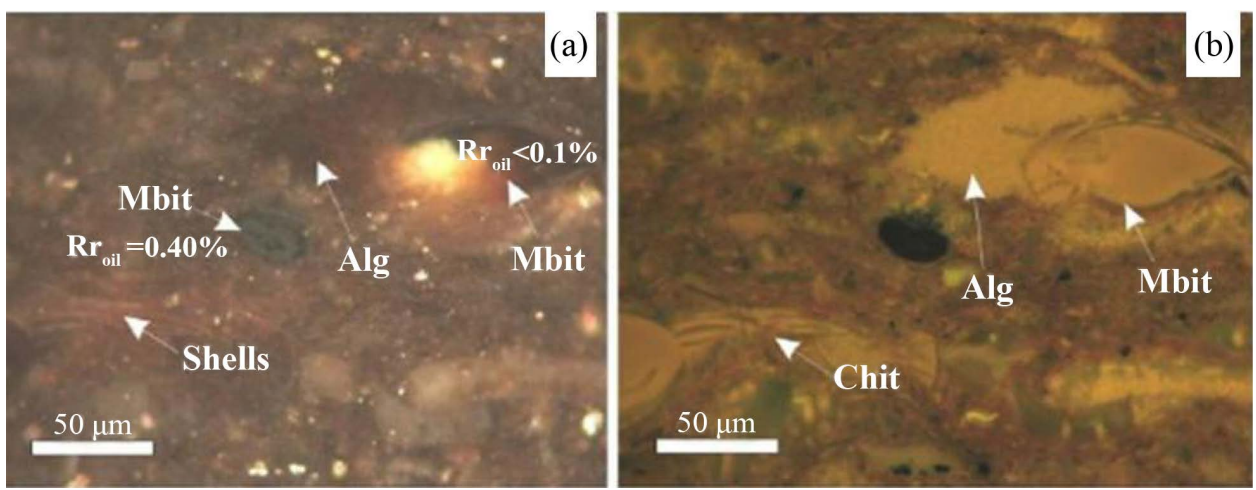

Figure 10. Types of migrabitumens, albertite (center) and wurtzilite (upper right), along with alginite under (a) white reflected light, (b) fluorescence mode.
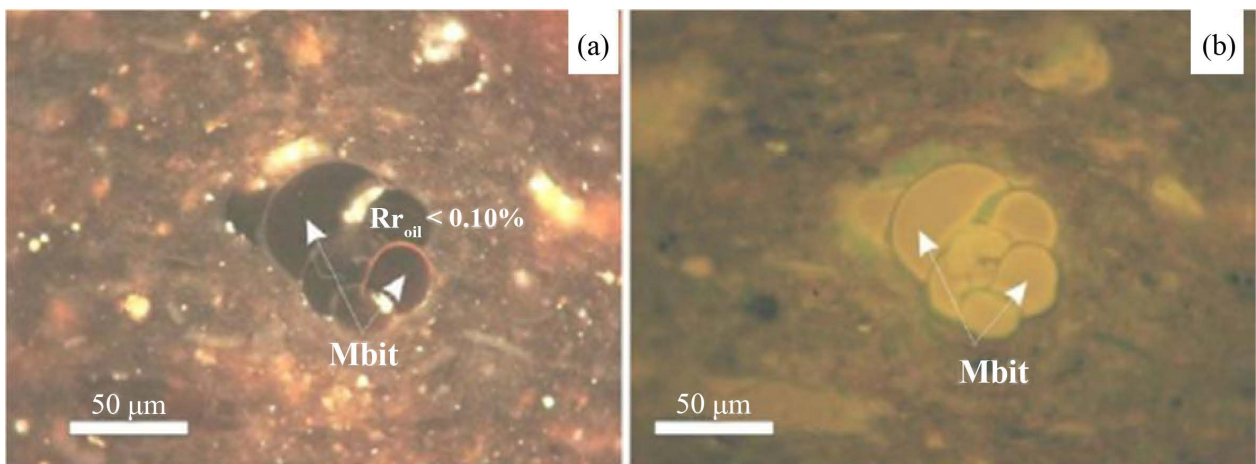

Figure 11. Wurtzilite (migrabitumen) filling the cavities of foraminifera under (a) white reflected light, (b) fluorescence mode.

second solid bitumen type is more reflective $\left(\mathrm{Rr}_{\text {oil }}=0.45 \%\right)$ and displays weak or no fluorescence. According to the same classification this bitumen is called albertite (Figure 12). This bitumen is usually associated with bituminite and its reflectance can be used as an alternative to vitrinite reflectance for thermal maturity assessment. This can be calculated after the following formula [33], which expresses the stochastic rela- 
tionship between vitrinite and bitumen reflectance in the same sample:

$$
R_{V}=0.618_{R B}+0.40
$$

where $R_{V}$ is the vitrinite reflectance and $R B$ is the bitumen reflectance. Applying Jacob's formula the equivalent vitrinite reflectance of $0.68 \%$ points to a thermal maturity at the early oil window, which is consistent with both the formation of solid bitumen and the fluorescence color and intensity of the alginite in this sample.

Both bitumen types are locally replaced by pyrite (Figure 13). Thermal alteration taking place at a limited extent resulted in the alteration of the bitumens' optical attributes (higher reflectance, cracks development, anisotropy).

Kerogen composition of this Sultani OS sample suggests a shallow marine depositional environment (shelf) with very limited fluvial input and rather dysoxic to anoxic conditions during deposition. The shelf was probably (at least partially) open basinwards allowing the exchange of green algae grown at greater water depths.

Previously published results indicate that Sultani OS is of low OM maturity level. Alnawafleh [23] reported that OS in central Jordan was deposited in a marine environment with contribution from terrestrial sources. According to the classification of Hutton [34], Sultani OS type is marinite. Marine OS is composed of lipid-rich OM derived from marine algae, acritarchs, and marine dinoflagellates [9]. The OM components
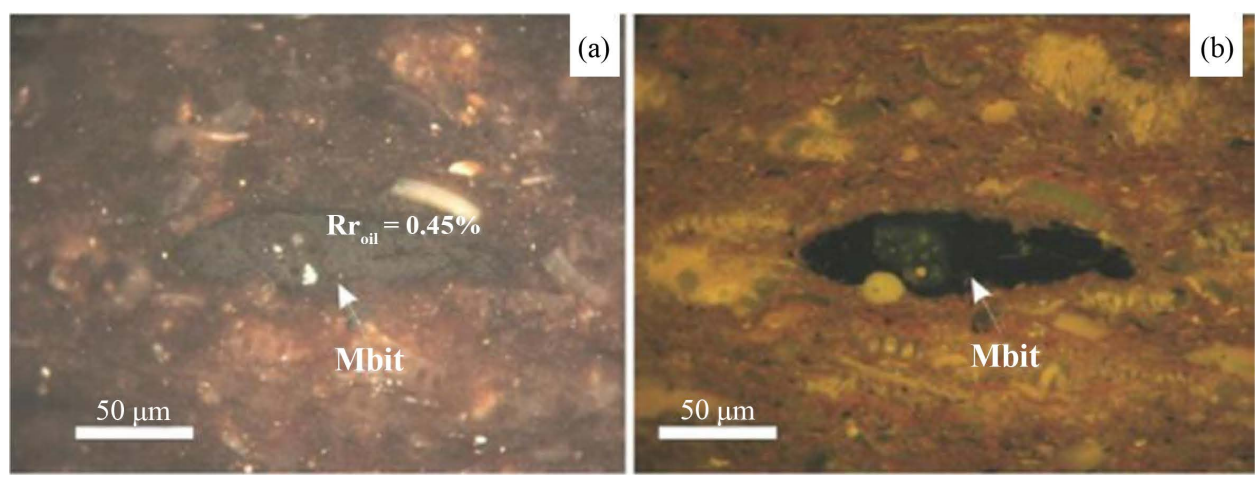

Figure 12. Albertite (migrabitumen) in bituminite matrix under (a) white reflected light, (b) fluorescence mode.
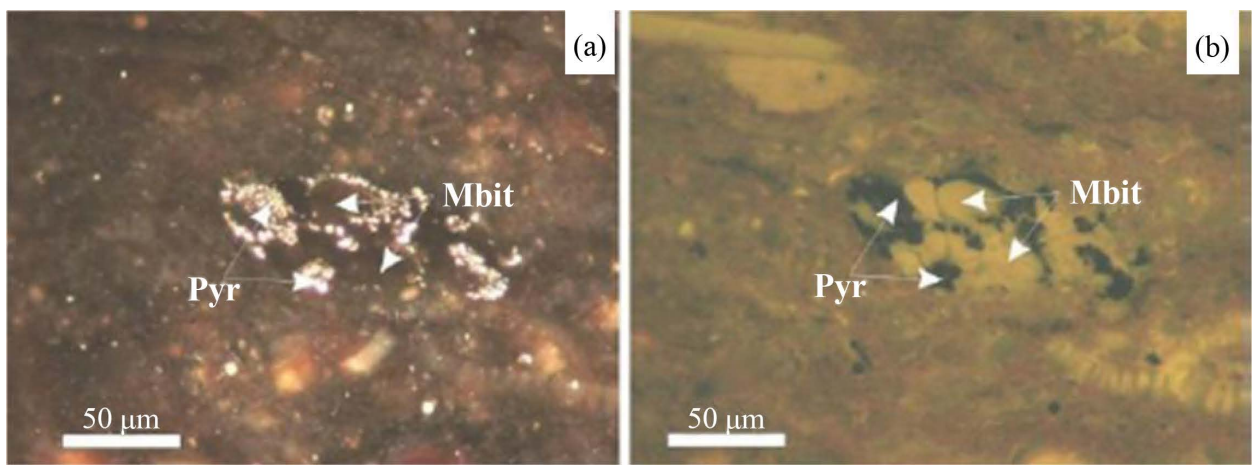

Figure 13. Development of pyrite in wurtzilite (Mbit) under (a) white reflected light, (b) fluorescence mode. 
in marinites are primarily lamalginite (maceral that describes dinoflagellate cysts and acritarchs) and bituminite derived chiefly from the degradation of this marine phytoplankton. Marinite may also contain small amounts of bitumen, telalginite, and vitrinite. Vitrinite is rare in OS and derived from humic matter of land plants and has moderate to high reflectance due to being redeposited from its primary location. Bituminite is an important component of marine OS. The origin of bituminite is likely to be of degraded algal or bacterial remains [9]. The source of OM in the Sultani OS is predominantly marine algae (oil-prone $\mathrm{OM}$ ) with minor contribution from terrestrial OM sources [23].

\section{Conclusion}

Sultani OS is a calcareous organic-rich sedimentary rock and not true shale, consisting of very fine-grained matrix; it shows rippled micro-laminated texture and muddy material of cryptocrystalline micrite. The rock is rich in Cretaceous microfossils filled with $\mathrm{OM}$. The filling OM is bitumen of the migrabitumen type. The geochemistry of major oxides and trace elements suggests high levels of OM production. The OM content reaches up to $17 \mathrm{wt} . \%$ with high oil-yielding capacity (up to $12 \mathrm{wt} . \%$ ). High TOC values of Sultani OS suggest that this is an excellent source rock. Vitrnite reflectance (mean $\mathrm{Rr}_{\mathrm{oil}}=0.85 \%$ ) is not a reliable parameter to assess the true thermal maturity of this OS sample; however solid bitumen reflectance suggests a thermal maturity in the early oil window. The main kerogen maceral is bituminite with alginite being second. There is also limited contribution from terrestrial OM found in the form of vitrodetrinite and fusinite. Two types of solid bitumens (migrabitumens) were observed. They are wurtzilite and albertite. Both bitumen types are locally replaced by pyrite. Results suggest that the Sultani OS is a marinite OS formed under marine conditions with limited contribution from terrestrial OM input.

\section{References}

[1] Peters, K.E., Walters, C.C. and Moldowan, J.M. (2005) The Biomarker Guide Vol. 1: Biomarkers and Isotopes in the Environment and Human History. 2nd Edition, Cambridge University Press, New York.

[2] Tissot, B.P. and Welte, D.H. (1984) Petroleum Formation and Occurrence. Springer-Verlag, New York, 699 p. http://dx.doi.org/10.1007/978-3-642-87813-8

[3] Hutton, A.C. (1987) Petrographic Classification of Oil Shales. International Journal of Coal Geology, 8, 203-231. http://dx.doi.org/10.1016/0166-5162(87)90032-2

[4] Taylor, G., Teichmüller, M., Davis, A., Diessel, C., Littke, R. and Robert, P. (1998) Organic Petrology. Gebrüder Bornatraeger, Berlin-Stuttgart, 704 p.

[5] Suárez-Ruiz, I. and Prado, J.G. (1995) Characterization of Jurassic Black Shales from Asturias (Northern Spain): Evolution and Petroleum Potential. In: Snape, C., Ed., Composition, Geochemistry and Conversion of Oil Shales, NATO A.S.I. Series, Series C: Mathematical and Physical Sciences, 455, 387-395.

[6] ICCP, International Committee for Coal Petrology (1971) International Handbook of Coal Petrology, 1st Supplement to 2nd Edition. Centre National de la Recherche Scientifique, Paris, France. 
[7] Suárez-Ruiz, I. and Crelling, J.C. (2008) Applied Coal Petrology. The Role of Petrology in Coal Utilization. Elsevier, Amsterdam, 388 p.

[8] Suárez-Ruiz, I. (2012) Organic Petrology: An Overview. In: Al-Juboury, A., Ed., Petrology-New Perspectives and Applications, InTech.

[9] Dyni, J.R. (2005) Geology and Resources of Some World Oil-Shale Deposits. USGS Report 2005-5294.

[10] Besieso, M. (2007) Jordan's Commercial Oil Shale Strategy. 27 th Oil Shale Symposium. Colorado, 15-17 October 2007.

[11] Alali, J. (2006) Jordan Oil Shale, Availability, Distribution, and Investment Opportunity. Paper NO rtos-A117. International Conference on Oils Shale: "Recent Trends in Oil Shale", Amman, 7-9 November 2006.

[12] Hamarneh, Y. (1998) Oil Shale Resources Development in Jordan. Unpublished Report, Natural Resources Authority, Amman, Jordan.

[13] Alali, J. and Sawaqed, S. (2006) Oil Shale Resources Development in Jordan. Unpublished Report, Natural Resources Authority, Amman, Jordan.

[14] Hufnagel, H. (1985) Investigation of the Oil Shale Deposits at Jurf Ed Darawish, El Hasa and Sultani, Bundesanstalt fur Geowissenschaften und Rohstoffe, Hannover. Technical Cooperation Project No. 78.2165.5.

[15] Powell, J.H. (1989) Stratigraphy and Sedimentation of the Phanerozoic Rocks in Central and South Jordan. Part B: Kurnub, Ajlun and Belqa Groups. Bulletin 11. Geological Mapping Division, Natural Resources Authority, Amman, 130 p.

[16] Abed, A.M. (2000) The Geology of Jordan and Its Environment and Water. Publication of the Jordanian Geologists Association, Amman. (In Arabic)

[17] Dill, H.G., Kus, J., Abed, A.M., Sachsenhofer, R.F. and Abul Khair, H. (2009) Diagenetic and Epigenetic Alteration of Cretaceous to Paleogene Organic-Rich Sedimentary Successions in Northwestern Jordan, Typical of the Western Margin of the Arabian Plate. GeoArabia, 14, 101-140.

[18] Andrews, I.J. (1992) Cretaceous and Paleogene Lithostratigraphy in the Subsurface of Jordan. Subsurface Geology Bulletin 5. Natural Resources Authority, Amman.

[19] Pufahl, P.K., Grimm, K.A., Abed, A.M. and Sadaqah, R.M. (2006) Upper Cretaceous (Campanian) Phosphorites in Jordan: Implications for the Formation of a South Tethyan Phosphorite Giant. Sedimentary Geology, 161, 175-205. http://dx.doi.org/10.1016/S0037-0738(03)00070-8

[20] Barjous, M. and Mikbel, S. (1990) Tectonic Evolution of the Gulf of Aqaba-Dead Sea Transform Fault System. Geologic and Tectonic Processes of the Dead Sea Rift Zone, 180, 49-59. http://dx.doi.org/10.1016/0040-1951(90)90371-e

[21] Ziegler, M. (2001) Late Permian to Holocene Paleofacies Evolution of the Arabian Plate and Its Hydrocarbon Occurrences. GeoArabia, 6, 445-504.

[22] Haq, B. and Al-Qahtani, A. (2005) Phanerozoic Cycles of Sea-Level Change on the Arabian Platform. GeoArabia, 10, 127-160.

[23] Alnawafleh, H. (2007) Geological Factors Controlling the Variability of Maastrichtian Bituminous Rocks in Jordan. PhD Thesis, Nottingham University, Nottingham.

[24] Powell, J.H. and Moh'd, B.K. (2011) Evolution of Cretaceous to Eocene Alluvial and Carbonate Platform Sequences in Central and South Jordan. GeoArabia, 16, 29-82.

[25] Abed, A., Arouri, K., Amiereh, B. and Al-Hawari, Z. (2009) Characterization and Genesis of Some Jordanian Oil Shales. Dirasat: Pure Sciences, 36, 7-17. 
[26] Hutton, A.C. (1988) Organic Petrography of Oil Shales. USGS Short Course, Denver.

[27] Alnawafleh, H.M., Fraige, F.Y., Al-Khatib, L.A. and Dweirj, M.K. (2015) Jordanian Oil Shales: Variability, Processing Technologies, and Utilization Options, Journal of Energy and Natural Resources, 4, 52-55. http://dx.doi.org/10.11648/j.jenr.20150404.11

[28] North, F.K. (1985) Petroleum Geology. Allen \& Unwin, Boston, 607 p.

[29] Peters, K.E. (1986) Guidelines for Evaluating Petroleum Source Rock Using Programmed Pyrolysis. American Association of Petroleum Geologists Bulletin, 70, 318-329.

[30] Murphy, A.E., Sageman, B.B. and Hollander, D.J. (2000) Black Shale Deposition and Faunal Overturn in the Devonian Appalachian Basin: Clastic Starvation, Seasonal Water-Column Mixing, and Efficient Biolimiting Nutrient Recycling. Paleoceanography, 15, 280-291. http://dx.doi.org/10.1029/1999PA000445

[31] Stow, D.A., Huc, A.Y. and Bertrand, P. (2001) Depositional Processes of Black Shales in Deep Water. Marine and Petroleum Geology, 18, 491-498. http://dx.doi.org/10.1016/S0264-8172(01)00012-5

[32] Meyers, P.A. and Doose, H. (1999) Sources, Preservation, and Thermal Maturity of Organic Matter in Pliocene-Pleistocene Organic-Carbon-Rich Sediments of the Western Mediterranean Sea. Proceedings of the Ocean Drilling Program, Scientific Results, 161, 383-390.

[33] Jacob, H. (1989) Classification, Structure, Genesis and Practical Importance of Natural Solid Oil Bitumen (“Migrabitumen”). International Journal of Coal Geology, 11, 65-79. http://dx.doi.org/10.1016/0166-5162(89)90113-4

[34] Hutton, A.C. (1991) Fluorescence Microscopy in Oil Shale and Coal Studies. Luminescence Microscopy and Spectroscopy: Quantitative and Qualitative Aspects. SEPM Short Course, 25, 107-115.

\section{Submit or recommend next manuscript to SCIRP and we will provide best service for you:}

Accepting pre-submission inquiries through Email, Facebook, LinkedIn, Twitter, etc. A wide selection of journals (inclusive of 9 subjects, more than 200 journals)

Providing 24-hour high-quality service

User-friendly online submission system

Fair and swift peer-review system

Efficient typesetting and proofreading procedure

Display of the result of downloads and visits, as well as the number of cited articles Maximum dissemination of your research work

Submit your manuscript at: http://papersubmission.scirp.org/

Or contact ojg@scirp.org 